\title{
Influence of Some Organic Acids Additives on Carcass Traits, Blood Biochemistry and Economical Efficiency in Broilers
}

\author{
Heba E. M. Salem¹ .; El-Gendi, G.M² and El-Garhy, O.H.M³. \\ Animal production Department, Faculty of Agriculture, Benha Univ., Egypt \\ Corresponding Author: heba.salem11@yahoo.com
}

\begin{abstract}
The present study was conducted to evaluate the effect of organic acids (citric, lactic and propionic) and their mixtures on carcass traits and blood biochemistry of broiler chickens. A total number of 480 broiler chicks (Ross) one-day old, nearly similar in live body weight were used in this study. Chicks were randomly divided into eight experiment groups each of 60 chicks in 3 replicates of birds. Chicks of the first group fed starter and grower basal diets without any supplementation and considered as a control group, the second, third and fourth groups were fed starter and grower basal diets with $5 \mathrm{~g} / \mathrm{kg}$ of either citric, propionic or lactic acids, respectively. While, the fifth group fed starter and grower basal diets with $5 \mathrm{~g} / \mathrm{kg}$ citric acid and $5 \mathrm{~g} / \mathrm{kg}$ propionic acid. The $6^{\text {th }}$ and $7^{\text {th }}$ groups fed starter and grower basal diets supplemented with $5 \mathrm{~g} / \mathrm{kg}$ citric and $5 \mathrm{~g} / \mathrm{kg}$ lactic acids, $5 \mathrm{~g} / \mathrm{kg}$ propionic and $5 \mathrm{~g} / \mathrm{kg}$ lactic .The $8^{\text {th }}$ group fed starter and grower basal diets supplemented with $5 \mathrm{~g} / \mathrm{kg}$ of each of Citric+ Propionic+ Lactic. Results obtained showed that chicks fed diet supplemented with citric and lactic acid, respectively had significantly increased the absolute and relative weights of carcass and total edible parts, the highest averages of plasma total protein, globulin and decreased plasma AST and ALT. Chicks fed on diet supplemented with the mixtures of Citric + Lactic + Propionic acid showed the highest averages of absolute and relative weights of carcass and total edible parts, plasma total protein, globulin and lowest plasma creatinine compared with the other treatments and control group. While chicks received diet supplemented with citric acid showed the highest value of plasma albumin and relative economical efficiency (REE). Generally, it is clearly observed from this study that using organics and their mixtures had improved the carcass yield, blood biochemistry and economical efficiency of broiler chickens compared with control. Citric acid at a level of $5 \mathrm{~g} / \mathrm{kg}$ diet seemed to be adequate to achieve the favorable results and is being recommended from the economic point of view.
\end{abstract}

Key words: Organic acids, carcass traits, blood parameters, economical efficiency, broilers

\section{Introduction}

Nowadays, the use of some antibiotics as growth promoter creates a huge problem for environmental condition and health of consumers. There is an increasing trend in using organic acid and mixtures, as alternatives to antibiotic growth promoters due to their inhibiting activity on the growth and development of pathogens in animal feed and gastrointestinal tract (Jovank et al. 2008). Acidification of diets with weak organic acids have been reported to decrease colonization of pathogen and production of toxic metabolites improved digestibility of protein, $\mathrm{Ca}, \mathrm{P}$, $\mathrm{Mg}, \mathrm{Zn}$ and served as substrate in the intermediary metabolism (Isabel and Santos (2009).

Organic acids feeding are believed to have several beneficial effects such as improving feed conversion ratio, growth performance, enhancing mineral absorption and speeding recovery from fatigue (Zeinb Abdo, 2004).

The mode of action for dietary organic acids is mainly believed to rely on their ability to acidify the diet and ultimately the contents of the digestive tract (Abdel-Fattah et al., 2008). Organic acids such as citric acid, numeric acid and formic acid enhance the digestibility of protein and amino acid by increasing gastric proteolysis. Organic acid reduces gastric $\mathrm{pH}$ which may boost the action of pepsin (Kirchgessner and Roth, 1988) arising proteolysis which activate the release of gastrin and cholecystokinin hormones and regulate the digestion and assimilation of protein (Hayat et al., 2014).

Also as alternatives to antibiotic growth promoters (Gunal et al., 2006). Several organic acids have been reported to improve growth performance, feed efficiency and mineral absorption when supplemented in no ruminant diets (Boling et al., 2000), are able to inhibit microorganism growth in the food, and consequently to preserve the microbial balance in the gastrointestinal tract and improve the solubility of the feed ingredients, digestion and absorption of nutrients (Deepa et al., 2011).

\section{Material and Methods}

This study was carried out at private poultry farm, at Moshtohor, Qaliubia governorate, Egypt during the period from 8 April to 20 May 2017. The biochemical parameters were conducted at the laboratories of Animal Production Department -Faculty of Agriculture- Benha University.

\section{Experiment of Design}

A total number of 480 broiler chicks (Ross) oneday old, of nearly similar live body weight were randomly chosen and divided into eight treatments each of 60 chicks in three replicated 20 chicks/each,as shown in the following table. 


\begin{tabular}{cl}
\hline Treatment & \multicolumn{1}{c}{ Description } \\
\hline T1 & Birds fed on basal diet only (control). \\
T2 & Birds fed on basal diet supplemented with $5 \mathrm{~g} / \mathrm{kg}$ citric acid \\
T3 & Birds fed on basal diet supplemented with $5 \mathrm{~g} / \mathrm{kg}$ propionic acid \\
T4 & Birds fed on basal diet supplemented with $5 \mathrm{~g} / \mathrm{kg}$ lactic aci \\
T5 & Birds fed on basal diet supplemented with $5 \mathrm{~g} / \mathrm{kg}$ citric $+5 \mathrm{~g} / \mathrm{kg}$ propionic acid \\
T6 & Birds fed on basal diet supplemented with $5 \mathrm{~g} / \mathrm{kgpropionic}+5 \mathrm{~g} / \mathrm{kg}$ lactic acid \\
T7 & Birds fed on basal diet supplemented with $5 \mathrm{~g} / \mathrm{kg}$ citric $+5 \mathrm{~g} / \mathrm{kg}$ lactic acid \\
T8 & Birds fed on basal diet supplemented with $5 \mathrm{~g} / \mathrm{kg}$ citric $+5 \mathrm{~g} / \mathrm{kg}$ propionic $+5 \mathrm{~g} / \mathrm{kg}$ lactic acid \\
\hline
\end{tabular}

\section{Housing and management of experimental Birds}

Chicks of all experimental treatments were kept under similar, standard hygienic and environmental conditions in separate pens with 10 birds $/ \mathrm{m}^{2}$ stocking density until the end of the experiment. Wood shaving was used at $10 \mathrm{~cm}$ depth as a litter. Artificial lighting was provided over the 23 hours daily during the whole experimental period. Fload brooders with gas heater were used to provide chicks with heat needed for brooding. Brooding temperature was mainted at $37^{\circ} \mathrm{c}$ during the first 5 days of chick's age, then decreased by $2^{\circ} \mathrm{c}$ weekly until the end of brooding period. Feed and water were offered ad-limitum. The basal diets were formulated in (Table, 1) according to the recommended requirements of NRC (1994).

Table 1. Composition and calculated analysis of basal diets.

\begin{tabular}{lcc}
\hline Ingredients \% & $\begin{array}{c}\text { Starter } \\
(\mathbf{0 - 4}) \text { wks. }\end{array}$ & $\begin{array}{c}\text { Grower } \\
\text { (4-6) wks. }\end{array}$ \\
\hline Yellow corn $(8.5 \%)$ & 61.00 & 66.00 \\
Soybean meal $(44 \% \mathrm{cp})$ & 35.50 & 26.00 \\
Corn gluten meal(60\% cp) & 0.00 & 1.00 \\
Vegetable oil & 0.00 & 3.00 \\
Di.calcium phosphate & 1.70 & 1.70 \\
Calcium carbonate & 1.10 & 1.20 \\
Sodium chloride & 0.30 & 0.30 \\
Vit.and.M.n. premix $*$ & 0.30 & 030 \\
DL. Methionine 99\% & 0.10 & 0.16 \\
Lysine hydrochloride $78 \%$ & 0.00 & 0.04 \\
Total & 100 & 100 \\
ME.(Kcal Kg) & 3135 & 2839 \\
Crude protein & 20.86 & 17.81 \\
Crude fat & 2.67 & 5.80 \\
Crude fiber & 2.73 & 2.49 \\
Calcium & 0.93 & 0.95 \\
Available P & 0.43 & 0.42 \\
Methionine & 0.46 & 0.47 \\
Methionine +Cysteine & 0.83 & 0.79 \\
Lysine & 1.21 & 0.99 \\
\hline M
\end{tabular}

Mixtures Vitamins and Minerals premix contains:

Vit. A, 12000000 IU: Vit. D3, 2000000 IU; Vit. E, 10g: Vit. K3, 2.0g: Vit. B1: 1.0g; Vit. B2, 5g ; Vit. B6;1.5g ; Vit. B12, 10mg; choline chloride, $250 \mathrm{~g}$; Biotin, $50 \mathrm{mg}$; folic acid, 1g; nicotinic acid, 30g; Ca Pantothenate, 10g; Zn,50g; Cu, 10g; $\mathrm{Fe}, 30 \mathrm{~g} ; \mathrm{Co}, 100 \mathrm{mg} ; \mathrm{Se}, 100 \mathrm{mg} ; \mathrm{I}, 1 \mathrm{~g} ; \mathrm{Mn}, 60 \mathrm{~g}$ and antioxidant , $10 \mathrm{~g}$ and complete to $3.0 \mathrm{~kg}$ by calcium carbonate.

\section{Parameters estimation and data collection:}

\section{Slaughtering and carcass characteristics}

Carcass characteristic for random sample of 5 birds from each treatment were performed at the end of the experimental period ( 6 weeks). Birds chosen were deprived from feed for 16 hours before slaughtering, after which they were individually weighed to the nearest $g$ and killed by cutting the throat and jugular veins near the first neck vertebra with a sharp knife. Birds were individually reweighed after complete bleeding. Shank and head were separated, the birds were then eviscerated and intestine, gizzard, lungs, spleen, liver, heart and all internal organs were removed. The carcass and giblets (empty gizzard, liver and heart) were separately weighed. The proportional weights to live weight of giblets, carcass ant total edible parts were calculated as follows:

Whereas:

$$
\begin{aligned}
& \text { Giblets weight }(\%)=\frac{\mathrm{Gw}}{\mathrm{LW}} \times 100 \\
& \text { Edible parts }(\%)=\frac{\mathrm{EW}+\mathrm{GW}}{\mathrm{LW}} \times 100
\end{aligned}
$$

LW=live weight

EW=eviscerated weight

$\mathrm{GW}=$ giblets weight

Blood samples for chemical analysis were individually obtained from 5 birds randomly chosen 
from each treatment at 6 weeks of birds' age. Heparinized blood samples were centrifuged at 2500 rpm for 15-min. Plasma samples were then stored in the deep freezer at approximately $-20 \pm 1^{\circ} \mathrm{C}$ until the time of chemical analysis. Plasma total protein, albumin, globulin , $\mathrm{A} / \mathrm{G}$ ratio, triglycerides, cholesterol , creatinine, uric acid, asparatate aminotransferase (AST) and alanine aminotransaminase(ALT) were calorimetrically determined using commercial kits.

\section{Economical Efficiency}

The economical efficiency (EE) was calculated according to the cost of one-kg feed (included the price of feed additives) and the price of one $\mathrm{kg}$ body weight gain during the same time of experiment.

The ecomical efficiency (EE) was calculated as the net revenue per unit of total coast. Relative economic efficiency (REE) was calculated assuming the REE of the control $=100$

\section{Statistical analysis:}

The statistical analysis for using the general Linear Model producer (SAS, 2004) significant differences between treatments were determined using Duncuns New Multiple-Range test (Duncun, 1955).

The statistical analysis for studied traits was carried out according to the following linear model:

$\mathrm{Xijk}=\mu+\alpha+$ eijk

Xijk $=$ the Nth observation

$\mu=$ overall mean

$\alpha \mathrm{I}=$ effect of the 1 th treatment

eijk $=$ the experimental error

\section{Results and Discussion}

\section{Carcass traits:}

Results obtained in Table (2) showed that broiler chicks fed diet supplemented with citric and lactic acid, respectively showed significantly increased absolute and relative weights of carcass and total edible parts compared with groups of birds fed diet supplemented with propionic acids as well as control group. While chicks of control group and those fed diet supplemented with lactic acid, respectively had significantly absolute and relative weights of giblets. These results might imply that broiler chicks CA had better immune response and disease resistance. These results agree with those reported by Talebi $\boldsymbol{e t}$ al.(2010) who stated that the added organic acids improved the relative weights of carcass, total edible parts and dressing of birds fed citric acid compared to the control group. In addition, Panda et al.(2011) observed better dressing percentage in broilers fed salts of formate and propionate in the diet. However, AbdEl-Hakim et al. (2009) who found no significant differences on broiler chicks fed $0.2 \%$ lactic acid on carcass characteristics. Hayam Abo ElMaaty (2017) concluded that the added organic acids (formic at levels $0.5,1.0 \%$ and citric acid at levels $2,3 \%$ in ducks diets)improved the total edible parts and dressing of birds compared to the control group.

It is clearly observed that broiler chicks fed diet supplemented with mixture of Citric + Lactic + Propionic acid, Propionic + Lactic acid and Citric + Lactic acid, respectively had significantly the highest relative and absolute weights of carcass and total edible parts compared with those of control group. This results agree with those reported by Sultan et al. (2015) who showed that blend of organic acids( citric acid $80 \mathrm{~g}$, lactic acid $52 \mathrm{~g}$, CuSO4 $10 \mathrm{~g}$ and phosphoric acid $92 \mathrm{~g}$ per Liter) given in drinking water to broiler chicks at levels, $0.5,1,1.5$ and $2 \mathrm{ml} /$ Liter of water, respectively significantly high carcass yield was observed in $2 \mathrm{ml} / \mathrm{liter}$. Liver weight was also significantly high at levels 1.5 and 2 $\mathrm{ml} /$ liter, however there was no significant effect of levels on heart weight.

The results obtained agree with those of Jang. (2008) who found that the supplementation of organic acid mixture (12\% lactic acid, 9\% formic acid and 5\% citric acid, $5 \%$ butyric acid and $6 \%$ phosphoric acid) at levels $0.1 \%$ and $0.2 \%$ that $0.2 \%$ organic acid mixture was effective in improving the gizzard weight of broilers.

Table 2. Least-square means and standard error pooled $(\mathrm{X} \pm \mathrm{S}$.E) for carcass traits of broilers of different experimental groups as affected by studied factors

\begin{tabular}{lcccccc}
\hline \multirow{2}{*}{ Treatments } & \multicolumn{2}{c}{ Carcass } & \multicolumn{2}{c}{ Giblets } & \multicolumn{2}{c}{ Total edible parts } \\
\cline { 2 - 6 } & $(\mathrm{g})$ & $(\%)$ & $(\mathrm{g})$ & $(\%)$ & $(\mathrm{g})$ & $(\%)$ \\
\hline Basal diet (control) & $1273^{\mathrm{c}}$ & $70.73^{\mathrm{b}}$ & $106.0^{\mathrm{bc}}$ & $5.93^{\mathrm{ab}}$ & $1379^{\mathrm{c}}$ & $76.66^{\mathrm{a}}$ \\
Citric acid & $1526^{\mathrm{a}}$ & $72.39^{\mathrm{a}}$ & $92.85^{\mathrm{d}}$ & $4.40^{\mathrm{d}}$ & $1619^{\mathrm{a}}$ & $76.79^{\mathrm{a}}$ \\
Propionic acid & $1183^{\mathrm{d}}$ & $57.52^{\mathrm{c}}$ & $98.70^{\mathrm{cd}}$ & $4.76^{\mathrm{cd}}$ & $1282^{\mathrm{d}}$ & $62.29^{\mathrm{b}}$ \\
Lactic acid & $1448^{\mathrm{b}}$ & $71.04^{\mathrm{a}}$ & $115.9^{\mathrm{ab}}$ & $5.71^{\mathrm{ab}}$ & $1564^{\mathrm{b}}$ & $76.76^{\mathrm{a}}$ \\
Citric + propionic & $1426^{\mathrm{b}}$ & $70.92^{\mathrm{b}}$ & $117.7^{\mathrm{a}}$ & $5.87^{\mathrm{ab}}$ & $1544^{\mathrm{b}}$ & $76.79^{\mathrm{a}}$ \\
Citric + lactic & $1226^{\mathrm{c}}$ & $72.14^{\mathrm{a}}$ & $101.8^{\mathrm{cd}}$ & $6.20^{\mathrm{a}}$ & $1328^{\mathrm{c}}$ & $78.35^{\mathrm{a}}$ \\
Propionic + lactic & $1506^{\mathrm{a}}$ & $73.89^{\mathrm{a}}$ & $105.3^{\mathrm{cd}}$ & $5.18^{\mathrm{bcd}}$ & $1618^{\mathrm{a}}$ & $79.08^{\mathrm{a}}$ \\
Citric + lactic + propionic & $1533^{\mathrm{a}}$ & $77.18^{\mathrm{a}}$ & $104.8^{\mathrm{cd}}$ & $5.40^{\mathrm{abc}}$ & $1638^{\mathrm{a}}$ & $82.58^{\mathrm{a}}$ \\
MSE & 115.1 & 3.64 & 3.59 & 0.28 & 117.6 & 3.64 \\
sig & $* * *$ & $* *$ & $* * *$ & $* * *$ & $* * *$ & $\mathrm{NS}$ \\
\hline
\end{tabular}

$\overline{\mathrm{a}, \mathrm{b}, \mathrm{c}}$ Means with different superscript in the same column are significantly different. *(P $\leq 0.05), * *(\mathrm{P} \leq 0.01), * * *(\mathrm{P} \leq 0.001)$ $\mathrm{NS}=$ not significant 
Plasma total protein, albumin, globulin and A/G ratio:

Chicks fed diet supplemented with citric acid showed significantly the higher values of plasma total protein (4.60), albumin (2.40) and globulin $(2.20 \mathrm{~g} / \mathrm{dl})$, followed by those fed diet with lactic acid, then by those fed diet with propionic acid and control group, respectively while birds fed diet supplemented with propionic acid showed the highest value of $\mathrm{A} / \mathrm{G}$ ratio (1.37) when compared with the other treatments applied and control group. Results obtained goes in agreement with those reported by Abdel-Fattah $\boldsymbol{e t}$ al. (2008) and Soliman et al. (2012) who found that supplementation of 3 types of organic acids (citric, lactic, and propionic) at 3 different levels. $0.5 \%, 1.0 \%$ and $1.5 \%$ on Ross broiler chicks showed significant effect on total protein, albumin and globulin. In addition, Ghazalah et al. (2011) found that chicks fed control diet was significantly higher plasma albumin, $\mathrm{A} / \mathrm{G}$ ratio and significantly lowered plasma globulin compared to PA at $0.5 \%$. These results indicated that supplemental organic acids may improve the immune response. Globulin level has been used as indicator of immune responses and source of antibody production. It is may be due to the improvement of intestinal amino acids absorption in acidic condition that consequently enhances protein synthesis, Yesilbag and Colpan (2006).

Chicks fed diet supplemented with mixture of organic acids (citric+lactic+propionic acid) showed significantly the highest levels of plasma total protein (5.05), albumin (2.22) and globulin $(2.80 \mathrm{~g} / \mathrm{dl})$, than those fed diet with propionic +lactic, citric+ lactic and citric + propionic and control group, while chicks fed diet with a mixture of citric+ propionic acid showed significantly the higher value of $\mathrm{A} / \mathrm{G}$ ratio (1.27) than the other treatments applied and control group. Results obtained agree with those reported by Ramigani et al. (2015) who showed that when broiler chicks fed on a mixture of organic acids were significantly $(\mathrm{P}<0.01)$ higher serum total protein, albumin, globulin and calcium levels were recorded in $4^{\text {th }}$ and $6^{\text {th }}$ wks. In addition to, Hassan. (2016) who concluded that organic acids had positive effect on plasma albumin of Cobb broiler chicken compared with control. Mixture of organic acids may improve the immune response. High globulin level and low $\mathrm{A} / \mathrm{G}$ ratio signified better disease resistance and immune response (Griminger, 1986).

Table 3. Least-square means and standard error pooled $(X \pm S . E)$ for plasma protein fractions at 6 wks of age of broilers of different experimental groups as affected by studied factors

\begin{tabular}{|c|c|c|c|c|c|}
\hline \multirow{2}{*}{ Treatments } & \multicolumn{2}{|c|}{$\begin{array}{c}\text { Total protein } \\
\text { (g/dl) }\end{array}$} & \multirow[t]{2}{*}{$\begin{array}{c}\text { Albumin } \\
\text { (g/dl) }\end{array}$} & \multirow[t]{2}{*}{$\begin{array}{c}\text { Globulin } \\
\text { (g/dl) }\end{array}$} & \multirow[t]{2}{*}{$\begin{array}{c}\text { A/G } \\
\text { Ratio } \\
\end{array}$} \\
\hline & $\begin{array}{c}\text { Levels } \\
\mathrm{g} / \mathrm{kg}\end{array}$ & & & & \\
\hline Basal diet (control) & 0.0 & $3.60^{c}$ & $1.90^{\mathrm{b}}$ & $1.70^{\mathrm{c}}$ & $1.15^{\mathrm{ab}}$ \\
\hline Citric acid & 5 & $4.60^{\mathrm{ab}}$ & $2.40^{\mathrm{a}}$ & $2.20^{\mathrm{ab}}$ & $1.10^{\mathrm{ab}}$ \\
\hline Propionic acid & 5 & $3.37^{\mathrm{c}}$ & $1.92^{\mathrm{b}}$ & $1.42^{\mathrm{c}}$ & $1.37^{\mathrm{a}}$ \\
\hline Lactic acid & 5 & $3.92^{\mathrm{bc}}$ & $2.10^{\mathrm{ab}}$ & $1.82^{\mathrm{bc}}$ & $1.16^{\mathrm{ab}}$ \\
\hline Citric + propionic & $5+5$ & $3.70^{\mathrm{c}}$ & $2.05^{\mathrm{ab}}$ & $1.62^{\mathrm{bc}}$ & $1.27^{\mathrm{a}}$ \\
\hline Citric + lactic & $5+5$ & $3.95^{\mathrm{bc}}$ & $2.02^{\mathrm{ab}}$ & $1.92^{\mathrm{bc}}$ & $1.09^{\mathrm{ab}}$ \\
\hline Propionic + lactic & $5+5$ & $3.45^{\mathrm{c}}$ & $1.90^{\mathrm{b}}$ & $1.55^{\mathrm{bc}}$ & $1.23^{\mathrm{a}}$ \\
\hline Citric+lactic+propionic & $5+5+5$ & $5.05^{\mathrm{a}}$ & $2.22^{\mathrm{ab}}$ & $2.80^{\mathrm{a}}$ & $0.86^{\mathrm{b}}$ \\
\hline MSE & - & 0.24 & 0.12 & 0.20 & 0.10 \\
\hline Sig & - & $* *$ & $* *$ & $* *$ & $* *$ \\
\hline
\end{tabular}

\section{Plasma cholesterol and triglyceride:}

Chicks fed diet supplemented with lactic, propionic and citric acid, respectively showed significantly the higher levels of triglycerides than those fed diet without any additives (control group). Chicks of control group and those fed diet supplemented with propionic acid showed the lowest levels of cholesterol (123.2 and $153.0 \mathrm{mg} / \mathrm{dl}$ ), respectively when compared with those fed diet supplemented with lactic or citric acid which had the higher values of plasma cholesterol (167.2 and 158.0 $\mathrm{mg} / \mathrm{dl}$ ), respectively. Chicks fed diet with lactic acid showed the higher values of plasma cholesterol and triglycerides. Results obtained disagree with those reported by Soliman et al. (2012) who stated that the mean values of serum cholesterol, triglycerides and total lipids did not differ due to organic acids supplementation. It is may be due to the mechanism of action through organic acids can decrease serum triglyceride content and possibly other parameters of lipid profile may interpreted through influence in decreasing the microbial intracellular PH. Thus, inhibits the action of important enzymes and forces the bacterial cell to use energy to release the acid protons, leading to an intracellular accumulation of acid anions (Abdel-fattah et $\boldsymbol{a l}$. 2008). Birds of control group and those fed diet with mixture of organic acids propionic +lactic showed the lowest 
level of plasma cholesterol followed by those fed diet with citric+propionic and citric+lactic acid, respectively, while birds fed mixture of organic acids citric+ lactic showed significantly the lowest level of plasma triglycerides when compared with the other treatments and control group. Results obtained agree with Zeinb Abdo, (2004), who reported that blood total lipids and cholesterol decreased significantly by dietary acidifiers, Also Ramigani et al. (2015)who showed that when broilers fed mixture of organic acids serum cholesterol levels decreased $(\mathrm{P}<0.01)$ in organic acid supplemented groups.

Table 4. Least-square means and standard error pooled $(\mathrm{X} \pm \mathrm{S}$.E) plasma chesterol and triglycerides at 6 weeks of age of broilers of different experimental groups as affected by studied factors

\begin{tabular}{lccc}
\hline \multicolumn{1}{c}{ Treatments } & Level $\mathrm{g} / \mathrm{kg}$ & Triglycerides $(\mathrm{mg} / \mathrm{dl})$ & Cholestrol $(\mathrm{mg} / \mathrm{dl})$ \\
\hline Basal diet (control) & 0.0 & $171.2^{\mathrm{d}}$ & 123.2 \\
Citric acid & 5 & $200.0^{\mathrm{bcd}}$ & 158.0 \\
Propionic acid & 5 & $205.5^{\mathrm{bcd}}$ & 153.0 \\
Lactic acid & 5 & $275.0^{\mathrm{a}}$ & 167.2 \\
Citric + propionic & $5+5$ & $172.2^{\mathrm{cd}}$ & 148.0 \\
Citric + lactic & $5+5$ & $161.7^{\mathrm{d}}$ & 148.5 \\
Propionic + lactic & $5+5$ & $250.5^{\mathrm{ab}}$ & 123.2 \\
Citric + lactic + propionic & $5+5+5$ & $224.7^{\mathrm{abc}}$ & 155.2 \\
MSE & - & 16.5 & 19.5 \\
Sig & - & $* * *$ & $\mathrm{NS}$ \\
a,b, c Means with different superscript in the same column & are significantly different. $*(\mathrm{P} \leq 0.05), * *(\mathrm{P} \leq 0.01),{ }^{* * *}(\mathrm{P} \leq 0.001)$ \\
NS=not significant. & &
\end{tabular}

Plasma aspartate aminotransferase (AST) and plasma alanine aminotransferase (ALT):

Results obtained in Table (5) showed that birds of control group and those fed diet supplemented with citric+ propionic and lactic acid, respectively insignificantly decreased plasma AST than the birds fed diet supplemented with propionic or citric acid, respectively. However, chicks fed diet supplemented with lactic, or propionic acid, respectively significantly decreased plasma ALT compared with those fed diet supplemented with citric acid and control group, respectively. This result agree with those reported by Ghazalah et al. (2011) who showed that broiler chicks fed $2 \%$ citric acid had significantly $(p<0.01)$ the highest value of ALT. However, insignificant differences observed for plasma AST. On the other hand, Tolba (2010) concluded that addition of $2 \mathrm{~g} \mathrm{CA} / \mathrm{kg}$ dietary feed had no effect on AST and ALT of broiler chicks. In addition to, Nourmohammadi et al. (2015) indicated that broiler chickens fed diet supplemented with $60 \mathrm{~g} / \mathrm{kg} \mathrm{CA}$ increase serum aspartate aminotransferase. The highest AST activity usually occurs during severe stress, followed by increased levels of glucocorticoids in serum (Gabriel et al., 2012). This may be related to the fact that a high level of CA may act as a stressor, causing dysfunction of internal organs (e.g. kidney, liver, heart, and skeletal muscle). Chicks fed diet supplemented with mixture of citric+propionic, citric+lactic+ propionic, propionic +lactic and citric+lactic, respectively decreased significantly of plasma AST when compared with control group. Results obtained disagree with Hayat et al .(2014) who reported that organic acid blend showed significantly lower values of alanine amino transaminase (ALT), aspartate amino transaminase (AST) in the treated groups compared to the untreated quails. The results obtained by Mousa, (2018) showed that Cobb broiler chicks fed diet supplemented with mixture of organic acids had significantly, lower serum AST and ALT than control group.

Table 5. Least-square means and standard error pooled $(\mathrm{X} \pm \mathrm{S} . \mathrm{E})$ for plasma (AST) and (ALT) of broilers of different experimental groups as affected by studied factors

\begin{tabular}{lccc}
\hline \multicolumn{1}{c}{ Treatments } & Level g/kg & AST(u/l)at & ALT $(\mathrm{u} / \mathrm{l})$ at \\
\hline Basal diet (control) & 0 & 17.25 & $246.50^{\mathrm{a}}$ \\
Citric acid & 5 & 28.00 & $212.25^{\mathrm{ab}}$ \\
Propionic acid & 5 & 23.00 & $205.00^{\mathrm{ab}}$ \\
Lactic acid & 5 & 21.00 & $177.50^{\mathrm{ab}}$ \\
Citric + propionic & $5+5$ & 18.25 & $147.25^{\mathrm{b}}$ \\
Citric + lactic & $5+5$ & 21.75 & $223.00^{\mathrm{ab}}$ \\
Propionic + lactic & $5+5$ & 24.25 & $170.75^{\mathrm{ab}}$ \\
Citric+ lactic+ propionic & $5+5+5$ & 24.75 & $156.50^{\mathrm{b}}$ \\
MSE & - & 3.36 & 25.04 \\
Sig & - & $\mathrm{NS}$ & $* *$ \\
a,b, c Means with different superscript in the same column are significantly different. ${ }^{*}(\mathrm{P} \leq 0.05),{ }^{* *}(\mathrm{P} \leq 0.01),{ }^{* * *}(\mathrm{P} \leq 0.001)$ \\
NS=not significant
\end{tabular}




\section{Plasma creatinine and uric acid:}

Efficiency of kidney function is often estimated by detecting the clearance rate of harmful metabolic by products like creatinine and uric acid from blood stream. The effect of treatments applied on plasma creatinine and uric acid are presented in Table (6)

Chicks fed diet supplemented with propionic, citric or lactic acids, respectively showed significantly the lowest average of plasma creatinine when compared with control group. However birds fed diet supplemented with lactic and citric acid, respectively showed significantly the higher levels of plasma uric acid $(7.15$ and $4.80 \mathrm{mg} / \mathrm{dl}$, respectively when compared with diet supplemented with propionic acid and control group, respectively. The results obtained agree with those reported by Hassan et al. (2016) who showed significant differences in uric acid between control and other treatments supplemented with diets containing 16, 14 and $12 \%$ crude protein supplemented with $1.5 \%$ CA. However, it disagree with those reported by Abdel Fattah et al., (2008) who showed that no significant effect on kidney (as measured by creatinine levels) by adding $3 \%$ citric acid on broiler chicks.
Birds fed diet supplemented with a mixture of (citric+lactic+propionic) showed significantly the lowest level of plasma creatinine $(0.13 \mathrm{mg} / \mathrm{dl})$ followed by (propionic +lactic), (citric+lactic) and control group $(0.17, \quad 0.20$ and $0.22 \mathrm{mg} / \mathrm{dl}$, respectively). However, a mixture of (citric +propionic) showed significantly the higher level of plasma creatinine $(0.37 \mathrm{mg} / \mathrm{dl})$, when compared with different treatments applied and control group. Chicks fed diet supplemented with a mixture of (citric+lactic) showed significantly the lowest level of plasma uric acid $(1.75 \mathrm{mg} / \mathrm{dl})$ when compared with different treatments applied and control group.

The results obtained agree with those reported by Hayat et al .(2014) who stated that organic acid showed significantly lower values in the treated groups compared to the untreated quails of urea and creatinine The findings of uric acid are coincide with Struike(1986) revealed that dietary addition of organic acid slightly reduce serum concentration of uric acid. This result could be referred to the better utilization of protein and amino acid digestibility. As uric acid is the major end product of protein metabolism.

Table 6. Least-square means and standard error pooled $(\mathrm{X} \pm \mathrm{S}$.E) for creatinine and uric acid of broilers of different experimental groups as affected by studied factors.

\begin{tabular}{ccc}
\hline Treatments & Creatinine $(\mathrm{mg} / \mathrm{dl})$ & Uric acid $(\mathrm{mg} / \mathrm{dl})$ \\
\hline Basal diet (control) & $0.22^{\mathrm{bc}}$ & $2.92^{\mathrm{cd}}$ \\
Citric acid & $0.20^{\mathrm{bc}}$ & $4.80^{\mathrm{b}}$ \\
Propionic acid & $0.15^{\mathrm{c}}$ & $2.72^{\mathrm{cd}}$ \\
Lactic acid & $0.21^{\mathrm{bc}}$ & $7.15^{\mathrm{a}}$ \\
Citric + propionic & $0.37^{\mathrm{a}}$ & $5.02^{\mathrm{b}}$ \\
Citric+lactic & $0.20^{\mathrm{bc}}$ & $1.75^{\mathrm{d}}$ \\
Propionic + lactic & $0.17^{\mathrm{c}}$ & $3.72^{\mathrm{bc}}$ \\
Citric+lactic+propionic & $0.13^{\mathrm{b}}$ & $3.40^{\mathrm{bc}}$ \\
MSE & 0.02 & 0.51 \\
Sig & $* *$ & $* * *$ \\
\hline
\end{tabular}

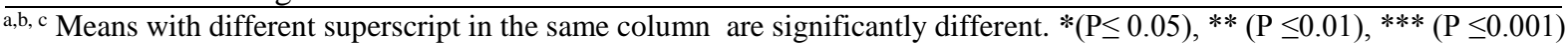
NS=not significant

\section{Eeconomical efficiency:}

Results obtained in Table (8) showed that the higher relative economic efficiency value (REE) was recorded by broiler chickens fed diet supplemented with citric acid (109.54\%) compared with other groups and control group as well which considered as $(100.0 \%)$. These results are relatively didn't go in the same previous trend mentioned in growth performance and FC traits in this study, this may attributed to the different in the cost of additives. This results agree with those reported by Abdel-Fattah $\boldsymbol{e t}$ al. (2008) who found that adding CA at both levels $(1.5$ and $3 \%)$ had the best values of either economic or relative economic efficiency compared with the control and other treatments (1.5-3\% acetic acid and 1.5-3\% lactic acid) of broiler chicks. Hassan et al.(2016) who found that the relative economic feed efficiency was the highest in birds fed $16 \%$ protein diet supplemented with citric acid compared with other treated groups. Asmaa El-Naggar et al.( (2017) they reported that ducks fed the basal diet supplemented with $0.5 \%$ formic acid and $3 \%$ citric acid recorded the best economical efficiency and compared to the other groups. 
Table 8. Least-square means and standard error (X+S.E) for economical efficiency of broilers of different experimental groups as affected by studied factors

\begin{tabular}{|c|c|c|c|c|c|c|c|c|c|c|c|}
\hline \multicolumn{12}{|c|}{ Economical efficiency } \\
\hline Treatments & $\begin{array}{l}\text { Average gain } \\
(\mathrm{kg})\end{array}$ & $\begin{array}{c}\text { Total } \\
\text { revenue } / \mathrm{kg} \\
\text { gain }(\mathrm{LE})\end{array}$ & $\begin{array}{c}\text { Total feed } \\
\text { intake/ } \\
\text { chicks }(\mathrm{kg}) \\
\end{array}$ & $\begin{array}{c}\text { Feed } \\
\text { cost/chick } \\
(\mathrm{LE})\end{array}$ & $\begin{array}{c}\text { Cost of } \\
\text { additives }\end{array}$ & $\begin{array}{c}\text { Total cost } \\
\text { of feed }\end{array}$ & $\begin{array}{l}\text { Other } \\
\text { costs } \\
(30 \%) \\
\end{array}$ & $\begin{array}{c}\text { Total } \\
\text { cost }\end{array}$ & $\begin{array}{c}\text { Net } \\
\text { revenue/ch } \\
\text { ick (LE) } \\
\end{array}$ & $\begin{array}{c}\text { Economical } \\
\text { efficiency } \\
(\mathrm{EE})\end{array}$ & REE \\
\hline Control & 1603.14 & 41.68 & 3.270 & 21.255 & 0 & 21.25 & 6.37 & 27.63 & 14.04 & 50.81 & 100 \\
\hline Citric & 1749.3 & 45.47 & 3.257 & 21.170 & 1.30 & 22.47 & 6.74 & 29.21 & 16.26 & 55.66 & 109.54 \\
\hline Propionic & 1748.04 & 45.44 & 3.222 & 20.943 & 3.14 & 24.08 & 7.22 & 31.31 & 14.13 & 45.13 & 88.82 \\
\hline Lactic & 1657.32 & 43.08 & 3.265 & 21.222 & 1.96 & 23.18 & 6.95 & 30.14 & 12.95 & 42.96 & 84.55 \\
\hline citric+propionic & 1690.92 & 43.94 & 3.270 & 21.255 & 4.49 & 25.75 & 7.72 & 33.47 & 10.47 & 31.28 & 61.56 \\
\hline Citric+lactic & 1649 & 42.87 & 3.222 & 20.943 & 3.22 & 24.16 & 7.24 & 31.41 & 11.46 & 36.48 & 71.79 \\
\hline Propionic+lactic & 1965 & 51.09 & 3.285 & 21.352 & 5.17 & 26.52 & 7.96 & 34.48 & 16.62 & 48.17 & 94.80 \\
\hline $\begin{array}{l}\text { Citric+lactic } \\
\text { + propionic }\end{array}$ & 1857.24 & 48.28 & 3.280 & 21.32 & 6.48 & 27.79 & 8.34 & 36.14 & 12.15 & 333.60 & 666.12 \\
\hline
\end{tabular}

Net revenue chick $(\mathrm{LE})=$ Total revenue/kg gain (LE)-Total feed cost / chick (LE)

$\mathrm{EEf}=$ Net revenue/chick $(\mathrm{LE}) /$ Total feed cost/ chick $(\mathrm{LE})$

Price of $1 \mathrm{~kg}$ Citric acid $=80 \mathrm{LE}$

Price of $1 \mathrm{~kg}$ propionic acid $=195 \mathrm{LE}$

Price of $1 \mathrm{~kg}$ Lactic acid $=120 \mathrm{LE}$

Price of $1 \mathrm{~kg}$ feed $=6.50 \mathrm{LE}$

Price of $1 \mathrm{~kg}$ bird $=26 \mathrm{LE}$ 


\section{References}

Abdel-Fattah, S.A.; El-Sanhouty, M.H.; ElMadnay, N.M. and Abdel-Azeem, F.(2008). Thyroid activity, some blood constituents, organs morphology and performance of broiler chicks supplemental organic acids, Int.J.poult.sci., 7(3):215-222.

Abdel-Hakim, A.A.; Cherian, G. and Ali, M. (2009). Use of organic acid, herbs and their combination to improve the utilization of commercial low protein broiler diets. Int. J. Poult. Sci. 8:14-20.

Hayam, M. A. Abo El-Maaty. (2017).Impact of using organic acids on growth performance, blood biochemical and hematological traits and immune response of ducks(Cairina moschata). Egypt. Poult. Sci.,vol (37)(iii): 907-925.

Asmaa, S.H.; EL-Naggar, Hayam, M. and Abo EL-Maaty, A.(2017). Impact of using organic acids on growth performance,blood biochemical and hematological traits and immune response of ducks(cairina moschata). egypt. poult. sci. vol (37)(iii): (907-925).

Boling, S.D.; Webel, D.M.; Mavromichalis, I., Parsons, C.M. and Baker, D.H. (2000). The effects of citric acid on phytate-phosphorus utilization in young chicks and pigs. J.Anim. Sci., 39(3):197-204.

Deepa, C.; Jeyanthi, G.P. and Chandrasekaran, D. (2011). Effect of phytase and citric acid supplementation on the growth performance, phosphorus, calcium and nitrogen retention on broiler chicks fed with low level of available phosphorus. Asian J. Poult. Sci.5: 28-34.

Denil, M.; Okan, F. and Celik, K. (2003). Effect of dietary probiotic, organic acid and antibiotic supplementation to diets on broiler performance and carcass yield.Pak. J. Nutr. 2(2):89-91.

Duncan, D.B. (1955): Multiple range and multiple F tests. Biometrics, 11:1-42.

Ghazalah, A.A.; Atta, A.M. ; Elkloub, K. ; Moustafa, M.E.L. and Shata, R.F.H. (2011) Effect of dietary supplementation of organic acids on performance, nutrients digestibility and health of broiler chicks. Int. J. Poult. Sci.10: 176184.

Griminger, P., (1986). Lipid Metabolism in "AvianPhysiology" Edited by P.D. Sturkie. 4th Edn.Springer-Verlag, Inc., New Work, NY.USA.

Gunal, M.; Yayli, G.; Kaya, O.; Karahan, N. and Sulak, O. (2006). The effects of antibiotic growth promoter, of broiler chickens. Ann. Biol. Res. 2(6):469-473.

Jovank, L; S. Markov; D. Olivera and Sredanovic, S. (2008). Herbs and organic acids as an alternative for antibiotic growth Promoters. Archiva Zootechnica 11:2, 5-11.
Kamal A.M, Ragaa, (2014). NM. Effect of dietary supplementation of organic acids on performance and serum biochemistry of broiler chicken. Nature and Science. 12(2):38-45.

Kirchgessner, M. and Roth, F.X. (1988). Ergotrope effektedurch organische sauren in der fekelaufzucht undschweinemast. Ubersichten zur tiererenährung, 16:93-108.

Mousa, M.A.M. (2018) Evaluation of using propionic acid and live yeast in diets low in protein and energy on broiler performance Egypt. Poult. Sci.vol. (38): (797-814).

NRC (1994). Nutrient Requirements of poultry $9^{\text {th }}$ rev.ed. Natl. Acad. Press., washington, DC Nourmohammadi, R. probiotic or organic acid supplementation on performance, intestinal microflora and tissue of broilers. International Journal of Poultry Science, vol.5, p. 149-155.

Hassan .A. Mohamed. (2016). Effect of utilization organic acid supplemented on broiler (ROS-308) feeding at pre-starter period breeding on basic performance parameters. Int.J.Adv.Res. Biol.Sci.3(6):76-81.

Hassan, Rashad, M.I.; Mosaad , G.M.M. and AbdEllah, A.M.(2016). Effect of feeding citric acidon performance of broiler ducks fed

Different protein levels .J.adv.vet.Res. 6:18-26.

Hayat, T.A. Sultan, R.U. Khan, khan,S.,Zahoor U.L Hassan, Ullah, R. and Aziz, t.,(2014). Impact of organic acid on some liver and kidney function tests in japanese quails, coturnix coturnix japonica. pakistanj.zool., 46: 1179-1182

Isabel, B. and Santos, Y. ( 2009) . Effects of dietary organic acids and essential oils on growth performance and carcass characteristics of broiler chickens. Journal of Applied Poultry Research, 18: 472-476.

Jang J.P. (2008). Comparative effect of Achillea and butyric acid on performance, carcass traits and serum composition, Khosravinia, H.and Afzali, N.(2015). Effect of high dietary levels of citric acid on productive performance, serum enzyme activity, calcium and phosphorus retention and immue response in broiler chickens. European poultry science.79:97.

Panda, S.; Sarka, S. K. and Mishra, A. (2011). Comparative study of organic acid salts solely as well asin combination on performance and gut health of broiler chicken. Journal of Inter academician, 15:122-129

Ramigani, V.R. ; Ramana, J.V.; Rao,D.S.; Shakila, S.and Suresh, J.(2015). Effect of dietary supplementation of organic acids on digestibility of nutrients and serum biochemical profile of broiler chicken. Indian Journal of Animal Nutrition, 32(3):300-304.

Ricke S. C., (2003): "Perspectives on the use of organic acids and short chain fatty acids as 
antimicrobials," Poultry Science, vol. 82, no. 4, pp. 632-639.

SAS (2004): Statistical Analysis Systems user's guide (8th ed.), SAS Insti-tute Inc., Cary, NC, USA, 2001.

Sturkie, P.D., (1986). "Avian Physiology". 4th Edn.Springer - Verlag, Inc., New Work, NY.

Soliman, N. K.; Alyoussef, Y. M. and Ghanem, N. B. (2012). Improving broiler performance and feed efficiency by adding organic acid to broiler diets. Egyptian Journal of Nutrition and Feeds., 15(2):393-404. 37.

Sultan, A.; Ullah, T.; Khan, S. and Khan, R.U. (2015). Effect of organic acid supplementation on the performance and ileal microflora of broiler during finishing period. Pakistan. J. Zool.,47:635-639.
Talebi, E., Zarei,A. and Abolfathi,M.E.(2010). Influence of three different organic acid on broiler performance. Asian. J. Poult. Sci., 4:7-11.

Tollba, A.A.H. (2010). Reduction of broilers intestinal pathogenic micro-Flora under normal or stressed condition. Egypt poult. Sci., 30(1): 249270.

Yesilbag, D. and Colpan, I. (2006). Effects of organic acid supplemented diets on growth performance, egg production and quality and on serum parameters in laying hens. Revue de Médicine Véterinarie, vol.157, p. 280-284.

Zeinb, M.A. Abdo, (2004). Efficacy of acetic acid improving the utilization of low proteinlow energy broiler diets. Egypt. Poult. Sci., 24: 123-141. 